\title{
Colorectal cancer: a review
}

\author{
Juan José Granados-Romero ${ }^{1}$, Alan Isaac Valderrama-Treviño ${ }^{2 *}$, \\ Ericka Hazzel Contreras-Flores ${ }^{3}$, Baltazar Barrera-Mera ${ }^{4}$, Miguel Herrera Enríquez ${ }^{2}$, \\ Karen Uriarte-Ruíz ${ }^{3}$, Jesús Carlos Ceballos-Villalva ${ }^{\mathbf{3}}$, Aranza Guadalupe Estrada-Mata ${ }^{3}$, \\ Cristopher Alvarado Rodríguez ${ }^{3}$, Gerardo Arauz-Peña ${ }^{3}$
}

\begin{abstract}
${ }^{1}$ Departamento de Cirugía General, Hospital General de México. Secretaría de Salud (SSa), Ciudad de México, México ${ }^{2}$ Laboratorio de inmunoterapia experimental e ingeniería de tejidos, Facultad de Medicina, Universidad Nacional Autónoma de México, Ciudad de México. México

${ }^{3}$ Programa de Apoyo y Fomento de la Investigación Estudiantil (AFINES), Facultad de Medicina, Universidad Nacional Autónoma de México, Ciudad de México. México

${ }^{4}$ Departamento de Fisiología, Facultad de Medicina, Universidad Nacional Autónoma de México, Ciudad de México México
\end{abstract}

Received: 17 August 2017

Accepted: 20 September 2017

\section{*Correspondence:}

Dr. Alan Isaac Valderrama-Treviño,

E-mail: alan_valderrama@hotmail.com

Copyright: () the author(s), publisher and licensee Medip Academy. This is an open-access article distributed under the terms of the Creative Commons Attribution Non-Commercial License, which permits unrestricted non-commercial use, distribution, and reproduction in any medium, provided the original work is properly cited.

\begin{abstract}
Colorectal cancer (CCR) is the third most common cancer worldwide in men and women, the second largest cause of death related to cancer, and the main cause of death in gastrointestinal cancer. The risk of developing this cancer is related to bad alimentary habits, smoking, intestinal inflammatory disease, polyps, genetic factors, and aging. Of the patients that are diagnosed with colorectal cancer $90 \%$ are older than 50, with a median age of 64 years; however, the disease is more aggressive in patients that are diagnosed at younger ages. According to the American Cancer Association, it was accounted for more than 49,700 deaths in 2015. The goal is to reduce the mortality rate with early diagnosis and treatment. Currently, the survival rate is used to predict a patient's prognosis. The patient is considered to have a positive familial history if a first-degree relative has been diagnosed with colorectal cancer or colonic polyps before the age of 60, or also if two or more first-degree relatives have been diagnosed with cancer or polyps at any age. There are several methods for detecting colorectal cancer, such as the guaiac test, immunochemical test of stool, DNA stool test, sigmoidoscopy, colonoscopy, and barium enema. The stage in which the cancer is detected determines the prognosis, survival, and treatment of the patient. Provide a review about generalities, genetic basis, risk factors, protective factors, clinical course, diagnostic methods, therapy and survival in colorectal cancer. Conducted research from different databases such as PubMed, Medline, MedScape, on the definition, genetic factors, classification, risk factors, protective factors, diagnostic methods, epidemiology, survival and treatment of colorectal cancer. Articles from 2000 to 2017 were included using the following keywords.
\end{abstract}

Keywords: Colorectal cancer, Mortality, Epidemiology, Risk factors, Survival, Tumoral markers

\section{INTRODUCTION}

Colorectal cancer is the third most common type of cancer in oncologic pathology. ${ }^{1}$ Currently, it is the most common malignant cancer in the gastrointestinal tract, representing $13 \%$ of all malignant tumors, and it is considered the second most common cause of death related to cancer affecting men as women in the same manner worldwide, developed and undeveloped 
countries, and it is expected to overcome the mortality rate of heart diseases in the coming years. ${ }^{2-4}$ It is a prevalent disease in those aged 65-74, with a higher prevalence in women ${ }^{5}$. However, this pathology is diagnosed more frequently in younger patients, due to risk factors such as obesity, sedentarism, bad nutritional habits (high in fats and proteins), smoking, and the progressive aging of the population. In patients with colorectal cancer, the clinical presentation depends on the location, size, as well as the presence or absence of metastases. The clinical presentation includes symptoms such as abdominal pain, alteration of chronic bowel habits, changes in bowel movements, involuntary weight loss, nausea, vomit, malaise, anorexia, and abdominal distensión. ${ }^{3}$ Distal cancers cause evident rectal bleeding in comparison to proximal cancer that can give mixed blood with stool, so it tends to occulted and in consequence, anemia may be presented as secondary sign. ${ }^{3}$ Among the unusual clinical findings we can find a peripheral lymphadenopathy especially the Virchow lymph node in the left supraclavicular space, and hepatomegaly from hepatic metastases, as well as loss of the muscular mass by cachexy. ${ }^{6}$ The carcinogenic models of the colorectal cancer models on colorectal cancer carcinogenesis include the suppressor or classic pathway, and it also include a mutator or alternative pathway. The first one is known as the pathway of chromosomal instability following a pattern of progression of adenoma present in $80 \%$ of sporadic colorectal cancer, and the second is known as the pathway of microsatellite instability where there are a wide range of mutations of genes that are present in $20 \%$ of sporadic cancer and $80 \%$ of hereditary colorectal cancer mainly by the APC $60 \%$, p53 70\%, DCC 70\%, KRAS $40 \%$ y BAX $50 \%{ }^{7}$ Colorectal cancer usually starts as polyp in the intestinal mucosa, however it can also exist as an initial benign lesion called adenoma that has the ability to transform into a malignant lesion depending on its histological presentation (Table 1), and its size (Table 2), of which $60 \%$ of cases are simple adenoma, and $40 \%$ are multiple adenomas. $24 \%$ of the patients with untreated polyps will develop cancer. ${ }^{8}$ Presently, it is classified under the Astler-coller-Dukes system or TNM system established by The American Joint Committee on Cancer. ${ }^{9}$ Which represents the stage of the colorectal cancer by categories. The letter $\mathrm{T}$ represents the spread of propagation extension through the layers of the colonic or rectal wall, the letter $\mathrm{N}$ indicates if there is presence in the lymph node, and $\mathrm{M}$ indicates metastasis in distant organs.

\section{EPIDEMIOLOGY}

According to Surveillance, Epidemiology and Final Results program, in the United States there were an estimated of 132,700 new cases of colorectal cancer in 2015. This represents $8 \%$ of all the new cases of cancer, and there were an estimated of 49,700 deaths from this disease, with a mortality rate of 8.1/100.000 habitants. Which mainly affects developed regions (25.1/100.000 habitants), while the rate is significantly inferior in undeveloped regions (3.9/100.000 habitants). ${ }^{10}$ However, a gradual decline in the incidence has been observed, which reflects the increase of early detection by colonoscopy with removal of precancerous lesions in adults from 50 to 75 years of age. ${ }^{11,12}$ The use of colonoscopy increased from $19.1 \%$ to $54 \%$ in 2013 . In the last report of GLOBOCAN 2012, colorectal cancer was reported as the third most common in men with 1361,000 cases representing $10 \%$ of all cancers, and it is the second most common type of cancer in women with 614, 000 cases representing $9.2 \%$ of all cancers. The occurrence for both genders oscillate in 1361,000 cases with a mortality of 694,000 (8.5\% of all cancers) which is inferior with more deaths $(52 \%)$ in the less developed regions of the world. ${ }^{13}$ The INEGI reported 74,685 deaths from cancer in 2010 (13\% of the deaths in Mexico) from which $5.4 \%$ are cause by colorectal cancer. Colorectal cancer may be caused by sporadic or non-hereditary related to mutation errors in DNA, transcriptional silencing of suppressor tumor genes, genes involved in the control of the cellular cycle, repair, and apoptosis or genetic in origin related to mutations in suppressor gene tumors such as APC, DCC, BRAF,PIK3CA, AKT, and TP53 or the presence oncogenes as K-RAS and CTNNB1. ${ }^{14}$ (Table 3) As well as chromosomal anomalies, gene mutations, epigenetic changes involving proliferation, differentiation, apoptosis and angiogenesis are also causes. ${ }^{15}$ However, it is currently considered biomarker that predicts the response to therapy through EGFR17. Sporadic colorectal cancer, by activating the oncogene K-RAS located on chromosome 12 shows mutation mainly in codon 12 and 13 (95\% of the mutations) and just $5 \%$ of the mutations are in codons $61,146,154$, these mutations are mainly observed in patients with metastasis. Associations with 12 codon present mucinous type cancer mutations, while mutations in codon 13 are related to non-mucinous cancer, however this type is more aggressive with higher metastatic rate. ${ }^{16-}$ ${ }^{18}$ A KRAS mutation can be considered as bad prognosis mainly in the codon 13, and is also considered to be a biomarker that predicts the response to therapy through EGFR. ${ }^{17}$ The genetic mechanism begins with an inactive mutation of the tumor suppressor gene APC, which is responsible for familial adenomatous polyposis, and approximately $85 \%$ of colorectal cancer without hereditary relationship. Some of the adenocarcinomas develop after a mutational activation of the B-catenin (CTNNB1) regulated by APC, or by a second mechanism initiated by the inactivation of a family of tumor suppressor genes involved in the repair of the DNA. These genes are known as MMR genes or Mismatch including the human homolog mutS (MSH2), the human homolog 1 Mutl, (MLH1), and the posmeiotic segregation gene increased type 2 (PMS2) including both in hereditary affections as well as sporadic colorectal cancer. Mutations always occur in specific ways, first those that affect the APC gene followed by those that affect the RAS gene. ${ }^{19}$ Changes in TP5, the suppressor tumor gene is affected in $50 \%$ of the cases and it tend to appear more towards at the end of the sequence. ${ }^{20}$ In the 
somatic alterations, it can affect the glicoproteic signal pathway WNT/B-catenin that is associated with cellular proliferation, tissue homeostasis, and its mutation is associated to human diseases such as congenital malformations, cancer, osteoporosis, and is found in $95 \%$ of patients with colorectal cancer. ${ }^{21,22}$ The rs59336 allele located in the intron of the TBX3 gen of the WTN/B catenin pathway has been associated with an increase risk in developing colorectal cancer. ${ }^{23}$

However, alterations in genes such as SMAD7 have been associated with affecting the progression of colorectal cancer, and there are three known variants of the SMAD7 gene (rs44939827, rs12953717, and rs4464248) in the $8 \mathrm{q} 21$ chromosome that increase the risk of colorectal cancer. ${ }^{24,25}$ However, these are not the only genetic errors that can influence the risk of colorectal cancer. ${ }^{26}$ Currently, metastases protective genes have been identified, such as KISS1, which connects to the KISS receptor. This is essential for the suppression of metastasis, and the survival rate significantly improves to high levels of KISS1 and KISS1R". ${ }^{27}$ Genes that protect against metastasis have been identified, such as KISS1, which connects to the KISS receptor. This is essential for the suppression of metastasis, and the survival rate significantly improves with high levels of KISS1.

Table 1: Histological variety and malignancy association.

\begin{tabular}{|lll|}
\hline $\begin{array}{l}\text { Histological } \\
\text { Type }\end{array}$ & $\begin{array}{l}\text { Percentage of } \\
\text { Colorectal } \\
\text { Cancer cases }\end{array}$ & $\begin{array}{l}\text { Percentage of } \\
\text { malignancy }\end{array}$ \\
\hline Tubular & $60-80 \%$ & $<5 \%$ \\
\hline Tubulovillous & $10-25 \%$ & $20-25 \%$ \\
\hline Villous & $5-10 \%$ & $35-45 \%$ \\
\hline
\end{tabular}

Table 2: Porcentual relation between size and malignancy.

\begin{tabular}{|ll|}
\hline Size $(\mathbf{c m})$ & Percentage of cases \\
\hline$<1 \mathrm{~cm}$ & $1.3 \%$ \\
\hline $1-2 \mathrm{~cm}$ & $19 \%$ \\
\hline$>2 \mathrm{~cm}$ & $46 \%$ \\
\hline
\end{tabular}

Table 3: Gen function and mutation.

\begin{tabular}{|c|c|c|}
\hline Gen & Function & Mutation \\
\hline APC & $\begin{array}{l}\text { Codifies a tumor suppressor protein that acts as an antagonist } \\
\text { of Wnt signal pathway. Migration and cellular adhesion }\end{array}$ & Colorectal Cancer \\
\hline DCC & Codifies netrin-1 protein, Tumor suppressor & Colorectal cancer, Esophageal cancer \\
\hline TP53 & Tumor suppressor & Colorectal cancer \\
\hline BRAF & $\begin{array}{l}\text { Map/Kinase pathway, related to cellular division and } \\
\text { differentiation and secretion. }\end{array}$ & $\begin{array}{l}\text { Colorectal cancer, Non Hodgking } \\
\text { lymphoma, Malignant melanoma, } \\
\text { Thyroid cancer, Lung carcinoma of } \\
\text { non small cells }\end{array}$ \\
\hline PIK3CA & $\begin{array}{l}\text { Codifies p1 } 10 \text { alpha working as a kinase in cellular pathway, } \\
\text { cellular proliferation division, migration and cellular survival. }\end{array}$ & $\begin{array}{l}\text { Colorectal cancer, Ovary cancer, } \\
\text { Breast cancer, Stomach cancer, Lung } \\
\text { cancer, Brain cancer }\end{array}$ \\
\hline P53 & $\begin{array}{l}\text { Tumor suppressor, stopping the cellular cycle, apoptosis and } \\
\text { DNA repair. }\end{array}$ & Hereditary cancer \\
\hline KISS1 & Metastasis suppressor by joining KISS1R & Colorectal cancer \\
\hline AKT1 & $\begin{array}{l}\text { Signal pathway, oncogenesis, cellular proliferation, cellular } \\
\text { survival apoptosis and angiogenesesis. Codifies serine and } \\
\text { treonin kinase PKB }\end{array}$ & Colorectal cancer \\
\hline SMAD4 & $\begin{array}{l}\text { Pathway of growing beta transforming factor (TGF- } \beta \text { ), } \\
\text { controls the adhesion of DNA for particular genes and } \\
\text { suppressor genes. }\end{array}$ & $\begin{array}{l}\text { Polyposis syndroms, Colon cancer, } \\
\text { Pancreas cancer }\end{array}$ \\
\hline K-RAS & $\begin{array}{l}\text { Oncogen Codifies KRAS, a GTPASE involve in the cellular } \\
\text { division differentiation and apoptosis. }\end{array}$ & Colorectal cancer \\
\hline CTNNB1 & $\begin{array}{l}\text { Cellular adhesion necessary for creation and maintenance of } \\
\text { epithelial layers for regulation of cellular growth. }\end{array}$ & $\begin{array}{l}\text { Colorectal cancer, Meduloblastoma } \\
\text { Ovary cancer }\end{array}$ \\
\hline
\end{tabular}

\section{RISK FACTORS}

Among the risk factors related to developing colorectal cancer, which is estimated that $35 \%$ can be explained by hereditary factors. Nevertheless, family history has great relevance for risk of colorectal cancer, as well as colon or rectal cancer, hereditary diseases such as familial adenomatous polyposis, hereditary colon cancer without polyposis which is known as Lynch syndrome. ${ }^{28}$ It is associated with gene mutations implicated in the pathway 
of repair of bad DNA coupling/ mating (MMR, mismatch repair) specifically MLH1, MSHS2, MSH6, and PMS2. The mutations in MLH1 and MLH2 are majority about $90 \%$ of the mutations found in families of hereditary colon cancer with or without polyposis. However APC germinal online mutations, repair MTHYU, SMAD4, BMPR (Alq3), STK11, represent less than 5\% of all cases of colorectal cancer. ${ }^{29}$ It is estimated that these genetic syndromes represent about $10 \%$ of all cases of colorectal cancer; however about $25 \%$ of cases the familial history contributes to an increased risk of developing colorectal cancer in the absence of these genetic syndromes ${ }^{30}$. Factors such as history of ulcerous colitis, Chron's disease, personal history of polyposis, colon, rectal, ovarian, endometrium, breast cancer, and diabetes mellitus are related to a $30-50 \%$ greater risk of developing colorectal cancer, and about $75 \%$ of the malignant tumors of the colon and rectum are presented without related any of these risk factors; The relationship between hyperplastic polyposis and cancer is controversial. Adenomatous polyps are common in adults which are over 50 years old, but most polyps will not turn malignant. Its histology and size determine its clinical relevance. Risk factors for malignancy in hyperplastic polyps include polyp size equal to or above $10 \mathrm{~mm}$, or dysplasia, right colon localization. A focus of an adenoma within the polyp (mixed polyp hyperplasticadenomatous); in which the presence of more than 20 hyperplastic polyps in the colon, and familial history of colon cancer. In a period of a clear evolution between 1015 years with define stages, iniciating as a minor dysplasia that progresses depending on the genetic modifications to moderate or severe. The dissemination pathways is determined by either hematic or lymphatic, which defines the speed of growth and the time of evolution of the disease, however there have been reported cases of implantation by surgical manipulation after a laparoscopic colectomy. ${ }^{3}$ The adenomatous polyps are common in adults over 50, but most of the polyps will not turn malignant. The histology and size will determine its clinical relevance. The risk factors for a hyperplastic polyp to turn malignant includes size equal to or above to $10 \mathrm{~mm}$, dysplasia, location in the right colon, a focus of adenoma inside another polyp (mixed hyperplasticadenomatous polyp), presence of more than 20 hyperplastic polyps in the colon, and familial history. It develops with a clear evolution between 10-15 years starting as mild dysplasia that progresses depending on the genetic modifications to moderate or severe. The dissemination pathways are either hematic or lymphatic, and defines the growing rate and the time of progression of the disease; however cases have been reported of surgical implantation following a laparoscopic colectomy. The adenomatous polyps are common in adults over 50, but most of the polyps will not turn malignant. The histology and size will determine its clinical relevance. The risk factors for a hyperplastic polyp to turn malignant includes size equal to or above to $10 \mathrm{~mm}$, dysplasia, location in the right colon, a focus of adenoma inside another polyp (mixed hyperplastic- adenomatous polyp), presence of more than 20 hyperplastic polyps in the colon, and familial history. It develops with a clear evolution between 10-15 years starting as mild dysplasia that progresses depending on the genetic modifications to moderate or severe. The dissemination pathways are either hematic or lymphatic, and defines the growing rate and the time of progression of the disease; however cases have been reported of surgical implantation following a laparoscopic colectomy. ${ }^{3}$

\section{PROTECTING FACTORS}

The ingestion of non-steroidal anti-inflammatory drugs reduce the risk of colorectal cancer, however the molecular basis have demonstrated, which regulates the overexpression of the receptor of the epidermal growth Factor (EGFR), which is overexpressed in the $80 \%$ of the cases colorectal cancer, as an early event in colorectal tumorigenesis. The overexpression of the cyclooxygenase 2 (COX-2) triggers the activation of the transcription factor of the c-Jun dependent protein activator 1 (AP-1) that binds to the promoter of EGFR; therefore selective COX-2 inhibitors can be used as quimiopreventive activity against colorectal cancer. ${ }^{31}$ However, it has been demonstrated that dietary high fiber ingestion is a factor of prevention against colorectal cancer and other tumors, as well as high consumption of fruits and vegetables, however, no association has been found for colorectal cancer, or association for separate ingestion of fruits and vegetables. $^{32}$ The variety in consumption was not associated with a decrease in the risk of colon cancer, but if there is an increased with a high in the variety in fruit consumption reflected in a $41 \%$ of higher risk for those who ingest more than 8 different fruits every two weeks. ${ }^{33}$

\section{DIAGNOSTIC METHODS}

Current screening methods targeting moderate risk populations (Table 4) aged 50 or more include the fecal occult blood test (TSOH) with the high sensibility based on the Guaiac or immunologic test (TSOHi) with an annual periodicity; sigmoidoscopy every 5 years with TSOH every 3 years, or colonoscopy every 10 years. ${ }^{34}$ Diagnostic methods are largely related to the overlife of a patient with colorectal cancer, however some methods such as fecal occult blood can present in false positive results that coincide in high consumption of red meat, vegetables, and fruits that may contain peroxidase versus persons with no bleeding condition that ingest vitamin $\mathrm{C}$ may result in a false positive test. ${ }^{3}$ Despite this, technology has enable the development of techniques such as PCR, which allows to identify biological genetic markers by doing its specific test, and its purpose is to identify mutations in specific gene related to colorectal cancer. Currently for the identification of colon and colorectal cancer concentrations of the homebox duodenal pancreatic transcription factor (PDX-1) in the development and proliferation of pancreas whose levels 
increase mainly in malignant cancer that of the pancreas, breast, colon, prostate, renal and metastasis versus low levels in primary tumors or null levels in healthy colon tissue, therefore it is considered biomarker in colorectal cancer. ${ }^{35-37}$

The hypoalbuminemia would constitute a simple and significant marker of bad prognosis, other tests such as sigmoidoscopy which present improvements day by day where $65-75 \%$ of adenomatous polyps, and $40 \%-65 \%$ of the colorectal cancers are within reach of sigmoidoscopy; however about $50 \%$ of the advance adenomas $(>1 \mathrm{~cm})$ and proximal colon cancer were undetectable in this method. ${ }^{3}$ Although it is the only technique that is of scrutiny, diagnosis and therapeutic management of the colon is a procedure that implies a higher cost, risk and discomfort for the patient compared to other tests. ${ }^{38}$ Notwithstanding, the overexpression of proteins and genetic factors, they can currently be considered as markers of patient bad prognosis factors such as high levels of mRNA and paxiline in colorectal cancer related to the histological tumor grade, tumor sizes, clinical TNM stage and remote metastases where it is shown that the prognosis of the patients with high level of paxiline was unfavorable versus low expressions of paxilline as well as shows a Pre-treatment hypoalbulinemia $(<3,5 \mathrm{~g} / \mathrm{dl})$ that is related independently with a lower survival after resection. Both globally and in colorectal cancer stage II plus hypoalbunemia, so to confirm these results the hypoalbuminemia would constitute a simple and significant marker of bad prognosis, available from the time of diagnosis. ${ }^{39,40}$

\section{SURVIVAL TO 5 YEARS}

Survival or survivorship is a value that predicts a patient's prognosis; to 5 years refers to the percentage in which a patient lives at least five years after the diagnosis of cancer; taking in to account the type and stage of the cancer, as well as particular factors in the treatment administrated (the genomic modifications of the cancer cells as well as the individual and their biological variability). The 5-year and 10-year relative survival rates for persons with colorectal cancer are $65 \%$ and $58 \%$, respectively. ${ }^{41}$ It is to say those patients who survive more than 5 years, after the diagnosis of colorectal cancer without taking into account age, histological type, or stage of the disease. In a study conducted by Wulaningsih et al. in patients diagnosed with cancer, it shows an inversely proportional relation to the levels of $\mathrm{LDH}$ (enzyme lactate dehydrogenase) and the survival is to say they were compared with the pre-diagnostic LDH levels, increasing the risk of death from prostate, lung, gastroesophagal, gynecologic and colorectal cancers, while high intervals near the diagnostic period are related with the overall and specific mortality of the cancer. ${ }^{42}$ The survival of patients diagnosed with colon, rectal and colorectal cancer is variable according to the type and stage. Patients which got stage IIIA or IIIB cancer have a better survival than those patients whose got stage II B cancer, patients so much so that survival in rectal cancer was better for some patients with stage III cancers than for some in stage II cancers. However in the study of Dobras et al; It shows a worse survival for patients in stage III with mutation in KRAS that in those patients with KRAS type wild IE without mutation in the oncogene, another of the genes related to survival is the expression of the gene KISS1 and KISSR which shows a direct proportional correlation with the survival of colorectal to greater expression of the same survivability increases 44.3 and 39.3 to 45.8 and $42.2 \%$ respectively. with the Gene expression the survival rate increases from 44.3 and $39.3 \%$ to a 73.7 and $67.9 \%$ respectively. Patients with low levels of KISS 1 showed in patients a remote metastasis; statistically significant., therefore KISS 1 could be a promising prognostic and therapeutic marker in colorectal cancer. ${ }^{43}$ As a leading cause of death in these patients approximately $50-60 \%$ of the patients diagnosed will develop metastasis. ${ }^{44}$ In general the fiveyears lifespan varies from $65 \%$ in the United States, $55 \%$ in other developed countries, $14 \%$ in Africa, and 39\% in developing countries. ${ }^{31}$ Survival ranges are significantly different by stage, $90 \%$ for localized disease, $68 \%$ for regional disease with lymphatic affection, and $10 \%$ for disseminated disease related to the early detection unlike other types of cancer in which the size of the tumor does not affect the prognosis of the disease; however the increase in the mortality rate is justified in the increase of the life expectancy in the population, in the relation of the increase of genetic alterations due to greater susceptibility to carcinogenic, immunosuppression and comorbidity of the patients which explains the greatest risk of developing colorectal cancer. ${ }^{33}$ Mortality rates are variable in terms of gender, with a very slight prevalence of female sex, in colon cancer (51 vs $49 \%$ ), and male sex in colorectal cancer (53 vs 46), mainly by liver metastases as a leading cause of death in these patients. ${ }^{2}$ Approximately $50-60 \%$ of the patients diagnosed will develop metastasis. ${ }^{44}$ Survivors may also suffer from bladder dys-function, sexual dysfunction, and negative body image. ${ }^{45,46}$

\section{DIAGNOSIS BY LOCATION}

Most tumors are localized in the rectum (37\%), and sigmoidal (31\%), being less frequent in ascending colon $(9 \%)$, cecum $(8 \%)$, descending colon $(5 \%)$, transverse colon $(4 \%)$, hepatic angle $(4 \%)$, and splenic angle $(2 \%) .{ }^{43}$ About $65 \%$ of colon cancers are distal to the splenic angle and highly detectable by sigmoidoscopy versus $35 \%$ of colon cancers that are proximal to sigmoidal and not detectable by flex sigmoidocopy. ${ }^{3}$

The recurrence of the disease is associated with the elevation of serum values of carcinoembryonic antigen (ACE) in the $60-70 \%$ of the cases, and is considered value increased the concentration of ACE highet $5 \mathrm{mg} / \mathrm{l}$ related to an unfavorable prognosis to the patient; however its value maintains significance mainly in stadium TNM II. ${ }^{27}$ 
Table 4: Comparison between diagnostic methods.

\begin{tabular}{|c|c|c|c|c|}
\hline Method & Mechanism & Sensibility & Specificity & Observation \\
\hline $\begin{array}{l}\text { Occult blood in } \\
\text { feces } \\
\text { (Guaiac Test) }\end{array}$ & $\begin{array}{l}\text { Detects the peroxidae of the } \\
\text { group Heme in blood that are } \\
\text { present in the feces }\end{array}$ & $\begin{array}{l}30-52 \% \\
\text { Can } \\
\text { increase to } \\
90 \% \text { if } \\
\text { used } 1-2 \\
\text { years. }\end{array}$ & $95.2 \%$ & $\begin{array}{l}\text { Not specific for human hemoglobin } \\
\text { and can provide false positive result } \\
\text { with food that present peroxidase } \\
\text { activity such as uncooked vegetables, } \\
\text { red meat, therefore the } \\
\text { recommendation is to withdraw } 3 \\
\text { days before the sample is taken, as } \\
\text { well as NSAIDS } 7 \text { days before. }\end{array}$ \\
\hline $\begin{array}{l}\text { Feces Inmuno- } \\
\text { histochemical }\end{array}$ & $\begin{array}{l}\text { Monoclonal antibody reaction } \\
\text { or specific polyclonal } \\
\text { antibodies against human } \\
\text { hemoglobin, albumin, or other } \\
\text { components of the blood feces. }\end{array}$ & $76.5 \%$ & $95.3 \%$ & $\begin{array}{l}\text { More specific than the Guaiac test } \\
\text { since it is reactive to the human heme } \\
\text { group. Ideal for population screening } \\
\text { A pharmacological or dietary } \\
\text { restriction is not necessary. }\end{array}$ \\
\hline $\begin{array}{l}\text { DNA } \\
\text { Analyhsis in } \\
\text { fecal resiuds }\end{array}$ & $\begin{array}{l}\text { PCR Identification of } \\
\text { mutations: Kras, ACP, p } 53 \text { and } \\
\text { high levels of PDX1 }\end{array}$ & $52 \%$ & $94.4 \%$ & \\
\hline $\begin{array}{l}\text { Rectal } \\
\text { Examination }\end{array}$ & $\begin{array}{l}\text { Just as initial evaluation of the } \\
\text { symptomatic patient }\end{array}$ & $4.9 \%$ & $97.1 \%$ & $\begin{array}{l}\text { It is not consider a screening test. It } \\
\text { allows the detection of masses. }\end{array}$ \\
\hline $\begin{array}{l}\text { Flexible } \\
\text { Sigmoidoscopy }\end{array}$ & $\begin{array}{l}\text { It is performed with a } \\
\text { endoscopy that allows the } \\
\text { examination of the mucus layer } \\
\text { until } 60 \mathrm{~cm} \text { of the anal margin } \\
\text { (rectum, colon sigmoid and } \\
\text { descendent colon) }\end{array}$ & $\begin{array}{l}58-75 \% \text { in } \\
\text { small } \\
\text { lesions } \\
72-86 \% \text { in } \\
\text { advanced } \\
\text { lesions }\end{array}$ & $94 \%$ & $\begin{array}{l}\text { Important reduction of the mortality } \\
\text { in colorectal cancer } \\
\text { Must be performed every } 5 \text { years }\end{array}$ \\
\hline Colonoscopy & $\begin{array}{l}\text { Detection of polyps or } \\
\text { abnormalities Screening } \\
\text { method for colorectal cancer }\end{array}$ & $91 \%$ & $94 \%$ & $\begin{array}{l}\text { Associated with a risk of perforation } \\
\text { of } 2 \% \text { Hemorrhage risk of } 0.5 \% \text { by } \\
\text { performing the polypectomy } \\
\text { Risk of respiratory distress, } \\
\text { arrhythmias and arterial hypotension }\end{array}$ \\
\hline $\begin{array}{l}\text { Endoscopic } \\
\text { capsule }\end{array}$ & $\begin{array}{l}\text { Ingested video camara for } \\
\text { intestinal pathology }\end{array}$ & $77 \%$ & $59 \%$ & \\
\hline Barium enema & $\begin{array}{l}\text { With double contrast barium, } \\
\text { consist in the administration of } \\
\text { barium and pressurize air into } \\
\text { the colon }\end{array}$ & $\begin{array}{l}61 \%- \\
100 \%\end{array}$ & $\begin{array}{l}100 \% \\
\text { patients that } \\
\text { cant } \\
\text { performed a } \\
\text { colonoscopy }\end{array}$ & $\begin{array}{l}\text { Risk: Perforation } 1 / 25,000 \\
\text { Mortality } 1 / 55,000 \text { cases } \\
\text { Limited efficiency, it is used when } \\
\text { colonoscopy is contraindicated or } \\
\text { when no other diagnostic method is } \\
\text { available. }\end{array}$ \\
\hline CT scan & $\begin{array}{l}\text { Image in ultrathin tissue } \\
\text { sections }(0.5,0.625 \text { o } 0.75 \mathrm{~mm})\end{array}$ & \multicolumn{3}{|c|}{$\begin{array}{l}\text { It allows the evaluation of cancer's dissemination, complications, } \\
\text { recurrence and treatment response. }\end{array}$} \\
\hline $\begin{array}{l}\text { Virtual } \\
\text { colonoscopy }\end{array}$ & $\begin{array}{l}\text { Variant of Computed } \\
\text { Tomography, where using } \\
\text { contrast media improves } \\
\text { differentiation with fecal } \\
\text { residues }\end{array}$ & \multicolumn{3}{|c|}{$\begin{array}{l}\text { Alternative of barium enema in patients with contraindication } \\
\text { colonoscopy such as anticoagulants, pulmonary fibrosis or allergy } \\
\text { to sedatives }\end{array}$} \\
\hline $\begin{array}{l}\text { Magnetic } \\
\text { resonance }\end{array}$ & $\begin{array}{l}\text { Distinguishes the } \\
\text { characteristics of the tumor } \\
\text { associated with metastasis }\end{array}$ & $75-90 \%$ & $96 \%$ & $\begin{array}{l}\text { Absence of ionizing radiation, less } \\
\text { invasive, with better resolution in soft } \\
\text { tissues so it can be evaluated local } \\
\text { and remote invasion }\end{array}$ \\
\hline $\begin{array}{l}\text { Endorectal } \\
\text { ultrasound }\end{array}$ & $\begin{array}{l}\text { Using a transducer of } 7.5-10 \\
\text { MHz requires a balloon with } \\
\text { saline to produce } 360^{\circ} \text { image, } \\
\text { allows the visualization of } \\
\text { several layers. }\end{array}$ & $69-97 \%$ & \multicolumn{2}{|c|}{$\begin{array}{l}\text { Main method for rectal cancer mainly stratification. } \\
\text { Local recurrence who presented local resections in } \\
\text { superficial lesions. }\end{array}$} \\
\hline PET scan & \multicolumn{4}{|c|}{$\begin{array}{l}\text { It allows the staging of the tumor, lymph node, mainly extra hepatic metastasis stage in a single } \\
\text { image session. }\end{array}$} \\
\hline
\end{tabular}


Likewise, the SEPT9 protein has been implicated as a biomarker for more than 10 years, it has been shown as a precise, reliable, fast, and convenient method for colorectal cancer. ${ }^{47}$

\section{TREATMENT}

Stage 0 cancer can be treated by removing cancer cells by colonoscopy. For stage I, II and III Cancer, it is necessary to perform surgery using radical colectomy of the segment involved with margins > $5 \mathrm{~cm}$., lymphadenectomy to the root of the nutrient vessel (minimum $12 \mathrm{~N}$ ), suspicious ganglion biopsy outside the resection field. It has been demostrated that the laparoscpic approach is as safe as the traditional open approach for colorectal cancer. ${ }^{48}$ In patients with metastases in distal organs the addition of irinotecan to Fluorouracil and Leucovorin was demostrated prolongs survival in patients and was considered the new first-line standard therapy for this disease in patients with stage III cancer receive complementary chemotherapy after surgery for 6 to 8 months, improving symptoms and prolonging survival in people with stage IV cancer primarily. ${ }^{49}$ The 5-Fluoracil continues to be the cytostatic mostly used in the treatment of colon cancer, those who make use of it or at least approach the fulfillment of the therapeutic standard, achieve better percentages of survival. Currently, the role of an antibody variant called Bevacizumab (Avastin) approved by the US Food and Drug Administration (FDA) has been studied by lowering vascular endothelial growth factor (VEGF), the main angiogenesis regulator, produced by normal and neoplastic cells 50 Preclinical trials have shown that a human monoclonal antibody against VEGF can inhibit the the growth of xenografts of human tumors. ${ }^{50,51}$

In addition, to its direct antiangiogenic direct effects becacizumab can improve direct antioantiangiogenic and may also improve the delivety of chemotherapy by alterating the tumor vasculature and lowering elevated interstitial pressure in the tumors. ${ }^{52}$ The addition to bevacizumab to IFL improved the global survival; compared to only IFL the IFL regime plus bevacizumab increases progression-free survival from a median of 6.2 months to 10.6 months, the overall response rate of 34.8 to $44.8 \%$ and the average response duration of 7.1 months to 10.4 months by means of the primary (becacizumab)) mechanism of tumor growth inhibition rather than citoreduction. ${ }^{53}$ However the use of IFL with or without bavacizumab increase in the incidence of thrombosis, hemorrhage, proteinuria, and hypertension ${ }^{54,55}$ Radiotherapy is usually used in combination with chemotherapy for stage III rectal cancer patients, indicated in those cases where the margin of surgical resection is compromised, as in the case of adherence or infiltration to neighboring organs or the retroperitoneal space. However patients with stage IV colorectal cancer that has disseminated to the liver, it should be taken into account, the various therapeutic approaches targeted specifically to the affected organs including ablation, chemotherapy or radiotherapy, cryotherapy or surgery. Patients with metastases present active the KRAS oncogene showing resistance to treatment with anti-EGFR antibodies, so you will have to perform an evaluation of the KRAS (mutated or normal) for anti-EGFR therapy: approximately 30-050\% of patients with colorectal cancer are known with mutated KRAS, which could indicate that $>50 \%$ of patients would respond to anti-EGFR therapy, however, only 40$60 \%$ of these patients will respond, patients with mutated KRAS denote a decrease in survival compared to patients with wild type KRAS without activation of the oncogene. ${ }^{56,57}$

\section{HEPATIC METASTASIS FROM COLORECTAL CANCER}

The most common site of metastases in patients with colorectal cancer is the liver, due to its anatomical location with respect to its portal circulation. The liver is the most common site of metastasis in patients with colorectal cancer because of its anatomical location with respect to its portal circulation. Approximately $14-18 \%$ of patients with colorectal cancer have been detected with this type of cancer from the first medical consultation and $10-25 \%$ at the time of primary colorectal cancer resection. ${ }^{58}$ The poor prognostic factors remain the presence of metastases, recurrent disease and the advancement of local tumors. Despite advances in chemotherapy, surgery remains the treatment of choice, overcoming other treatments such as cryosurgery or radiofrequency ablation. Surgical treatment of isolated metastasis is a well-established treatment for selected patients and achieves a 5-year survival of between 39 and $58 \%$. It has been reported that the 5-year survival rate following the surgical procedure for liver metastasis is $25-44 \%$, with an intraoperative mortality of $0-6.6 \%$. Modern surgical techniques performed at major hepatobilliary centers have shown that $70 \%$ of hepatectomy can be achieved with a mortality of less than $5 \%$. With the help of Liver resections, the 5-year survival rate, even in those with a positive margin of less than 1 $\mathrm{mm}$, could be increased to $25 \%$. In cases where there are sufficient surgical margins $(<1 \mathrm{~mm}), 5$-year survival rates could be up to $40 \%$. It is vital to know the predisposing factors, the mechanisms, the diagnostic methods, the treatment of liver metastases, due to their anatomical situation in the abdominal cavity. The adoption of more and better programs in the health system is extremely important, with objectives focused on prevention, early diagnosis and adequate treatment that help the survival and prognosis of patients. ${ }^{59-61}$

\author{
Funding: No funding sources \\ Conflict of interest: None declared \\ Ethical approval: Not required
}




\section{REFERENCES}

1. Smith RET, Renaud RC, Hoffman E. Colorectal cancer market. Nat Rev Drug Discov. 2004;3:471-2.

2. Dobre M, Dinu DE, Panaitescu E, Bîrlă RD, Iosif $\mathrm{CL}$, Boeriu $\mathrm{M}$, et al. KRAS gene mutations prognostic factor in colorectal cancer? Rom J Morphol Embryol 2015;56:671-8.

3. Calva AM, Acevedo Tirado MT. Revisión y actualización general en cancer colorrectal. Revista de Radiología México. 2009;1:99-115.

4. Siegel RL, Miller K, Jemal A. Cancer Statistics, 2015. CA Cancer J Clin. 2015;65:5-29.

5. Galano R, Rodríguez Z, Casáus A. Cancer de colon: Seguimiento posoperatorio. Revista Cubana de Cirugía. 1997;36(1):59-63.

6. Mitchel SC. From Colonic Polyps to Colon Cancer: Pathophysiology, Clinical Presentation and Diagnosis. Clin Lab Med. 2005;25:135-77.

7. Kelsen D, Daly J, Kern S, Levin B, Tepper J, Van Cutsem E. Principles and Practice of Gastrointestinal Oncology. $2^{\text {nd }}$ Editon. Lippincott Williams and Wilkins; 2008.

8. DeVita V, Lawrence T, Rosenberg S. Cancer: Principles and practice of Oncol. $9^{\text {th }}$ Editon Lippincott Williams and Wilkins; 2011.

9. Silva AC, Hara AK, Leighton JA, Heppell JP. Ct Colonography with Intravenous Contrast Material: Varied Appearances of Colorectal Carcinoma. Radiographics. 2005;25:1321-34.

10. Cancer Mondial. Statistical Information System. International Agency for Research on Cancer; 1977.

11. Cress RD, Morris C, Ellison GL, Goodman MT. Secular changes in colorectal cancer incidence by subsite, stage at diagnosis, and race/ethnicity, 19922001. Cancer. 2006;107(5):1142-52.

12. Siegel RL, Ward EM, Jemal A. Trends in colorectal cancer incidence rates in the United States by tumor location and stage, 1992-2008. Cancer Epidemiol Biomarkers Prev. 2012;21:411-6.

13. Centers for Disease Control and Prevention, National Center for Health Statistics. National Health Interview Surveys, 2000, 2013. Public use data files, 2001, 2014.

14. Juárez-Vázquez C, Rosales-Reynoso M. Cancer colorrectal (CCR): alteraciones genéticas y moleculares. Gaceta Médica de México. 2014;150:154-64.

15. Russo A, Rizzo S, Bronte G, Silvestris N, Colucci $\mathrm{G}$, Gebbia N, et al. The long and winding road to useful predictive factors for anti-EGFR therapy in metastatic colorectal carcinoma: the KRAS/BRAF pathway. Oncology. 2009;77(1):57-68.

16. Bazan V, Agnese V, Corsale S, Calò V, Valerio MR, Latteri MA, et al. Specific TP53 and/or Ki-ras mutations as independent predictors of clinical outcome in sporadic colorectal adenocarcinomas: results of a 5-year Gruppo Oncologico dell'Italia Meridionale (GOIM) prospective study. Ann Oncol. 2005;16(4):50-5.
17. Bazan V, Migliavacca M, Zanna I, Tubiolo C, Grassi N, Latteri MA et al. Specific codon 13 K-ras mutations are predictive of clinical outcome in colorectal cancer patients, whereas codon $12 \mathrm{~K}$-ras mutations are associated with mucinous histotype. Ann Oncol. 2002;13(9):1438-46.

18. Oliveira C, Velho S, Moutinho C, Ferreira A, Preto A, Domingo E, et al. KRAS and BRAF oncogenic mutations in MSS colorectal carcinoma progression. Oncogene. 2007;26(1):158-63.

19. Yang YH, Lim SB, Kim MJ, Chung HJ, Yoo HW, Byeon JS, et al. Three novel mutations of the APC gene in Korean patients with familial adenomatous polyposis. Cancer Genet Cytogenet. 2010; 200(1):34-9.

20. Fearon ER, Vogelstein B. A genetic model for colorectal tumorigenesis. Cell. 1990;61:759-67.

21. MacDonald B, Tamai K, He X. Wnt/ $\beta$-catenin signaling: components, mechanisms, and diseases. Dev Cell. 2009;17(1):9-26.

22. Thorstensen L, Lind GE, Løvig T, Diep CB, Meling GI, Rognum TO, et al. Genetic and epigenetic changes of components affecting the WNT pathway in colorectal carcinomas stratified by microsatellite instability. Neoplasia. 2005;7:99-108.

23. Tomlinson IP, Webb E, Carvajal-Carmona L, Broderick P, Howarth K, Pittman AM, et al. A genome-wide association study identifies colorectal cancer susceptibility loci on chromosomes 10p14 and 8q23.3. Nat Genet. 2008;40:623-30.

24. Levy L, Hill CS. Alterations in components of the TGF-beta, superfamily signaling pathways in human cancer. Cytokine Growth Factor Rev. 2006;17:4158.

25. Broderick P, Carvajal-Carmona L, Pittman AM, Webb E, Howarth K, Rowan A, et al. A genomewide association study shows that common alleles of SMAD7 influence colorectal cancer risk. Nat Genet. 2007;39:1315.

26. Nissar S, Sameer AS, Rasool R, Chowdri NA, Rashid F. Polymorphism of the DNA Repair Gene XRCC1 (Arg194Trp) and its role in Colorectal Cancer in Kashmiri Population: a Case Control Study. Asian Pac J Cancer Prev. 2015;16(15):638590.

27. Moya P, Esteban S, Fernandez-Suarez A, Maestro M, Morente M, Sánchez-Carbayo M. KiSS-1 methylation and protein expression patterns contribute to diagnostic and prognostic assessments in tissue specimens for colorectal cancer. Tumour Biol. 2013;34(1):471-9.

28. Gala M, Chung DC. Hereditary colon cancer syndromes. Seminars in Oncology. 2011;38:490-9.

29. Aaltonen L, Johns L, Järvinen H, Mecklin J, Houlston R. Explaining the familial colorectal cancer risk associated with mismatch repair (MMR)-deficient and MMR-stable tumors. Clin Cancer Res. 2007;13:356-61.

30. Zhang K, Civan J, Mukherjee S, Patel F, Yang H. Genetic variations in colorectal cancer risk and 
clinical outcome. World J Gastroenterol. 2014;20 (15):4167-77.

31. Li H, Zhu F, Boardman LA, Wang L, Oi N, Lui K, et al. Aspirin Prevents Colorectal Cancer by Normalizing EGFR Expression. EBioMedicine. 2005;2(5):447-55.

32. Sánchez AR, Martín FM, Palma MS, López PB, Bermejo LM, Gómez CC. Fiber-type indication among different pathologies. Nutr Hosp. 2015; 31(6):237-83.

33. Leenders M, Siersma PD, Overvad K, Tjonneland A, Oslen A, Boutron-Ruault MC, et al. Subtypes of fruit and vegetables, variety in consumption and risk of colon and rectal cancer in the European Prospective Investigation into Cancer and Nutrition. Int J Cancer. 2015;1;137(11):2705-14.

34. National Comprehensive Cancer Network Guidelines (NCCN Guidelines). Colorectal Cancer Screening. Washington: NCCN Guidelines; 2014.

35. Ashizawa S, Brunicardi FC, Wang XP. PDX-1 and the pancreas. Pancreas. 2004;28:109-20.

36. Wang XP, Li ZJ, Magnusson J, Brunicardi FC. Tissue MicroArray analyses of pancreatic duodenal homeobox-1 in human cancers. World J Surg. 2005; 29:334-8.

37. Ballian N, Liu SH, Brunicardi FC. Transcription factor PDX-1 in human colorectal adenocarcinoma: A potential tumor marker? World J Gastroenterol. 2008;14:5823-6.

38. Jack S. Screening for colorrectal cancer. Gastroenterol Clin North Am. 2008;37:97-115.

39. Cheng-jin Z, Shuang-kuan D, Xing-bo D, Min G. Expression of Paxillin is Correlated with Clinical Prognosis in Colorectal Cancer Patients. Med Sci Monit. 2015;21:1989-95.

40. Borda F, Borda A, Jiménez J, Zozaya JM, Prieto C, Gómez M, et al. Predictive value of pre-treatment hypoalbuminemia in prognosis of resected colorectal cancer. Gastroenterol Hepatol. 2014; 37(5):289-95.

41. Miller KD, Siegel RL, Lin CC, Mariotto AB, Kramer JL, Rowland JH, et al. Cancer Treatment and Survivorship Statistics, 2016. Ca Cancer J Clin. 2016;66:271-89.

42. Wahyu W, Lars H, Hans G, Hakan M, Mats L, Niklas H, et al. Serum lactate dehydrogenase and survival following cancer diagnosis. British Journal of Cancer. 2015;113(9):1389-96.

43. Zhu C, Takasu C, Morine Y, Bando Y, Ikemoto T, Saito Y, et al. KISS1 Associates with Better Outcome via Inhibiting Matrix Metalloproteinase-9 in Colorectal Liver Metastasis. Ann Surg Oncol. 2015;22(3):1516-23.

44. Chao MW, Wang LT, Lai CY, Yang XM, Cheng $\mathrm{YW}$, Lee $\mathrm{KH}$, et al. eIF4E binding protein 1 expression is associated with clinical survival outcomes in colorectal cancer. Oncotarget. 2015; 15;6(27):24092-104.

45. Den Oudsten BL, Traa MJ, Thong MS, et al. Higher prevalence of sexual dysfunc- tion in colon and rectal cancer survivors compared with the normative population: a population-based study. Eur J Cancer. 2012;48:3161-70.

46. Liu L, Herrinton LJ, Hornbrook MC, Wendel CS, Grant M, Krouse RS. Early and late complications among long-term colorectal cancer survivors with ostomy or anastomosis. Dis Colon Rectum. 2010;53:200-12.

47. Song L, Li Y. SEPT9: A Specific Circulating Biomarker for Colorectal Cancer. Adv Clin Chem. 2015;72:171-204.

48. Arribas-Martin A, Díaz-Pizarro-Graf JI, MuñozHinojosa JD, Valdés-Castañeda A, Cruz-Ramírez O, Bertrand MM. Laparoscopic versus open surgery for colorectal cancer. A comparative study. Cir Cir. 2014;82(3):274-81.

49. Herbert H, Fehrenbacher L, Novotny W, Cartwright $\mathrm{T}$, Hainsworth J, Heim W, et al. Bevacizumab plus Irinotecan, Fluorouracil, and Leucovorin for Metastatic Colorectal Cancer. N Engl J Med. 2004; 2335-42.

50. Ferrara N, Gerber HP, LeCouter J. The biology of VEGF and its receptors. Nat Med. 2003;9:669-76.

51. Kim KJ, Li B, Winer J, Armanini M, Gillett N, Phillips HS, et al. Inhibition of vascular endothelial growth factor-induced angiogenesis suppresses tumour growth in vivo. Nature. 1993;362:841-4.

52. Willett CG, Boucher Y, di Tomaso E, Duda DG, Munn LL, Tong RT, et al. Direct evidence that the VEGF-specific antibody bevacizumab has antivascular effects in human rectal cancer. Nat Med. 2004;10:145-7.

53. Kabbinavar F, Hurwitz H, Fehrenbacher L, Meropol NJ, Novotny WF, Lieberman G, et al. Phase II, randomized trial comparing bevacizumab plus fluorouracil (FU)/leucovorin (LV) with FU/LV alone in patients with metastatic colorectal cancer. $\mathrm{J}$ Clin Oncol. 2003;21:60-5.

54. Yang JC, Haworth L, Sherry RM, Hwu P, Schwartzentruber DJ, Topolian SL, et al. A randomized trial of bevacizumab, an anti-vascular endothelial cell growth factor antibody, for metastatic renal cancer. N Engl J Med. 2003 349(5):427-34.

55. Jain RK. Normalizing tumor vasculature with antiangiogenic therapy: a new paradigm for combination therapy. Nat Med. 2001;7:987-9.

56. Lièvre A, Bachet JB, Le Corre D, Boige V, Landi B, Emile JF, et al. KRAS mutation status is predictive of response to cetuximab therapy in colorrectal cancer. Cancer Res. 2006;66(8):3992-5.

57. Knijn N, Mekenkamp LJ, Klomp M, Vink-Börger ME, Teerenstra S, Meijer JW, et al. KRAS mutation analysis: a comparison between primary tumours and matched liver metastases in 305 colorectal cancer patients. $\mathrm{Br} \mathrm{J}$ Cancer. 2011; 104(6):1020-6.

58. Manfredi S, Lepage C, Hatem C, Coatmeur O, Faivre J, Bouvier AM. Epidemiology and 
management of liver metastases from colorectal cancer. Ann Surg. 2006;244:254-9.

59. Adam R, Hoti E, Bredt LC. Estrategias oncoquirúrgicas en el cancer hepático metastásico. Cir Esp. 2011;89(1):10-9.

60. Mahmoud N, Bullard Dunn K. Metastasectomy for Stage IV Colorectal Cancer. Dis Colon Rectum. 2010;53(7):1080-92.

61. de Jong MC, Pulitano C, Ribero D, Strub J, Mentha G, Schulick RD, et al. Rates and patterns of recurrence following curative intent surgery for colorectal liver metastases. An international multiinstitutional analysis of 1669 patients. Ann Surg. 2009;250(3):440-8.

Cite this article as: Granados-Romero JJ, Valderrama-Treviño AI, Contreras-Flores EH, Barrera-Mera B, Enríquez MH, Uriarte-Ruíz K, et al. Colorectal cancer: a review. Int J Res Med Sci 2017;5:4667-76. 